\title{
3) PHYSIOLOGY AND BEHAVIOUR
}

\section{Isolation of a sheep placental hormone inducing lactation and growth}

\author{
J. MARTAL and J. DJIANE \\ Laboratoive de Physiologie de la Lactation, \\ Centre national de Recherches zootechniques, I.N.R.A., \\ 78350 Jouy-en-Josas (France)
}

An ovine lactogenic hormone (Ovine Placental Lactogen: OPL; Ovine Chorionic Somatomammotrophin: OCS) was isolated from sheep placentae at IOO-I20 days of pregnancy. Its main biophysical, biochemical and immunological properties were determined, and the placental localization of its cellular synthesis shown.

The patterns of prolactin-like and growth hormone-like activities were measured in pregnant sheep. OCS produced normal mammary growth without prolactin. With cortisol, OCS induced milk secretion in pregnant sheep without prolactin. OCS lactogenic activity was demonstrated in vitro in cultures of mammary gland.

Growth activity of OCS was shown by injections of OCS in hypophysectomized rats. Moreover, this hormone is bound to the same cellular receptors as the ovine growth hormone.

The high levels of OCS in faetal blood suggest the important role of this placental hormone in faetal growth.

\section{Effect of exogenous $17-\beta$ oestradiol supply at the end of gestation on ewe milk yield}

\section{DELOUIS ( $\left.{ }^{(}\right)$, M. TERQUI $\left({ }^{2}\right)$, J. PONT $\left({ }^{1}\right)$, P. PETREQUIN $\left({ }^{3}\right)$,} B. MIRMAN $\left({ }^{3}\right)$ and M. COTTIER $\left(^{4}\right)$

(1) Laboratoire de Physiologie de la Lactation, I.N.R.A., 78350 Jouy-en-Josas

(2) Station de Physiologie de la Reproduction, I.N.R.A., 37380 Nouzilly.

(3) Domaine Expérimental de Brouëssy, I.N.R.A., Magny-les-Hameaux, 78470 Saint-Rémyles-Chevreuse.

(4) Confédération Générale des Producteurs de Lait de Brebis et des Industricls de Roquefort, 36, avenue de la République, I2103 Millau.

In the ewe, œstrogens, among other hormones, control the development of the mammary gland during pregnancy and the appearance of copious milk secretion at the time of parturition. Single or repeated injections of I 7 - $\beta$ œstradiol after day I 40 of pregnancy, inducing parturition, may affect milk yields during machine milking or nursing.

One single injection of ostradiol benzoate ( $15 \mathrm{mg}$ ) on day $\mathrm{I}_{44}$ produced.

I) a significant increase $(\mathrm{P}<0.05)$ of milk yields during machine milking for 28 days and of weight gain (Io-3o days) of suckled lambs;

.2) a significant decrease $(\mathrm{P}<0.05)$ of milk yields during machine milking ( 180 days)after weaning. 
The positive significant effect of these treatments was observed mainly in single pregnant ewes; this observation was correlated with a significant increase of milk yields during machine milking when I $7-\beta$ ostradiol was injected to sheep selected for their low plasma ostrogen levels during pregnancy. Hormonal treatments at the end of pregnancy, increasing plasma levels of prolactin, thyroxin and corticoids, were without effect on milk yiclds during machine milking for 28 days.

One single injection of cestradiol benzoate $(15 \mathrm{mg})$ on day $\mathrm{I}_{44}$ of pregnancy produced a significant increase of the secretory activity of the mammary tissue, however, the development of the mammary gland was unchanged. This treatment did not modify the milk composition and dicl not seem to affect the subsequent fertility of treated ewes as compared with controls.

\title{
Maternal behaviour in sheep : mechanisms of mother-young recognition
}

\author{
P. POINDRON $\left({ }^{*}\right)$ and J. P. SIGNORET \\ Station de Physiologie de la Reproduction, \\ Centre de Recherches de Tours, I.N.R.A., \\ Nonsilly 37380 Monnaie \\ (*) Adresse actuclle : \\ Dept. of Animal Science. The University of Westem Anstralia, \\ Nedlands, WA 6009 (Australie)
}

The inadapted reactions of the ewe can lead to difficulties in the practice of slieep husbandry: refusal of lambs, difficulties in fostering as in adaptation to artificial feeding. The study of maternal behaviour can help in solving these problems. The results presented here only deal with the mutual recognition of lamb and ewe.

Some individual recognition is accomplished at a distance by bleats; however, the success of a suckling attempt at a short distance depends on ewe identification of the lamb by olfaction. Ewe anosmia eliminates lamb discrimination. Such females allow any young to suckle, the behavioural sequence lcading to suckling being disorganized.

This indicates that the maternal bond is established by olfactory cues during a critical period postpartum; the role of other sensory information develops later through the learning process.

4) EConomics

\section{Working time in sheep farming}

\author{
J. BASSEZ, M. GRILLOT, J. GUILLET $(*)$, \\ R. GUGGER and J. M. MANNO (**)
}

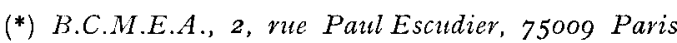

(**) I.T.O.V.I.C., I49, vue de Bercy, 75579 Paris Cedex 12

While references have already been published, systematic study of the working time for different activities in sheep farming systems was only completed in I976. The B.C.M.E.A. and the I.T.O.V.I.C. tape record oral descriptions of the activities concerned as they occur, so that 